\title{
American Cockroach Antigen IgG Antibody Measurement
}

National Cancer Institute

\section{Source}

National Cancer Institute. American Cockroach Antigen Ig G Antibody Measurement. NCI Thesaurus. Code C130138.

A measurement of the American cockroach (Periplaneta americana) antigen IgG antibody in a biological specimen. 